\title{
Pengembangan Buku Teks Matematika Kelas 8 Dengan Model ADDIE
}

\author{
Andhi Soesilo, Ashiong Parhehean Munthe \\ soesiloandhi@gmail.com, ashiong.munthe@uph.edu \\ Guru Matematika dan Fisika Sekolah Saint Peter Jakarta, Pascasarjana FIP Universitas Pelita Harapan
}

The Development of Grade 8 Mathematics Textbook with ADDIE Model

\begin{abstract}
Textbook is one of the primary resources to support teaching and learning. From the survey of the target school, the current secondary mathematics textbook does not match with Curriculum 2013 and heavy in size. Based on that survey, need analysis was conducted and it was recommended that the requirement of the textbook aligned with 2013 Curriculum, using proper English, and light in size. This research purpose is to produce the secondary mathematics textbook that matches the school's need. The method of research is Research and Development with model of ADDIE. The study was conducted in a private school in Jakarta with 96 students of grade 8 and 10 teachers in 2018. Instruments used are need analysis, validity expert, and test. Analysis of data use description of expert judgment based on content, language and design criteria and descriptive statistic for pre-test and post-test. The result was the textbook is valid and matches with the needs of that school.
\end{abstract}

Keywords: Textbook, Curriculum 2013, Research And Development, ADDIE

\section{Article Info}

Received date: 17 Februari 2020 Revised date: 7 September 2020 Accepted date: 24 September 2020

\section{PENDAHULUAN}

Dalam kegiatan belajar mengajar, diperlukan media pembelajaran sebagai alat untuk menyampaikan dan menjelaskan materi pembelajaran. Salah satu media belajar utama dalam pembelajaran di kelas adalah buku teks yang menggunakan kompetensi dasar dan inti serta layak digunakan oleh kementerian pendidikan dan kebudayaan (Kemendikbud, 2016: 2). Dalam penggunaan di sekolah, buku pelajaran dapat tidak sesuai dengan kurikulum nasional sehingga menimbulkan masalah tidak tercapainya standar kompetensi (You, Lee, \& Craig, 2019: 4). Faktor-faktor lain yang menimbulkan kendala menggunakan buku teks adalah harga, berat, dan penggunaan kertas (Millar \& Schrier, 2015: 177). Hal ini ditemukan saat survey di sekolah yang diteliti, dimana buku pegangan matematika yang dipakai yaitu New Syllabus Mathematics 2 tidak sesuai dengan kurikulum nasional 2013 dan adanya kendala penggunaan fisik seperti berat beserta ketebalan halaman.

Guru memilih dan menentukan media pembelajaran yang sesuai dan cocok sesuai dengan kebutuhan sekolah (Nurrita, 2018). Dalam hal ini, kebijakan sekolah menetapkan bahwa buku teks matematika berbahasa Inggris dan sesuai kurikulum 2013. Berdasarkan kebijakan tersebut dan survey kebutuhan, maka diadakan analisis kebutuhan yang merekomendasikan dibuatnya buku teks matematika kelas 8 yang sesuai dengan kurikulum 2013 dan berbahasa Inggris.

Dalam penggunaannya di kelas, buku teks dapat berbeda satu dengan yang lain dari institusi pendidikan yang menggunakannya. Pada umumnya, buku teks ini membuat konten pelajaran dari materi yang diajar di kelas dengan tingkatan yang disesuaikan dengan usia pembelajar. Hal ini terkait dengan standar pembelajaran matematika kelas 8 yang mengacu pada kurikulum 2013 yang digunakan sekolah tersebut (Kemendikbud, 2016). Dalam kurikulum 2013 ini, ditetapkan kompetensi inti, kompetensi dasar dari kompetensi spiritual, sikap, pengetahuan dan keterampilan yang menjadi standar pengajaran suatu mata pelajaran dengan tingkatan pembelajaran dalam jangka waktu tertentu. Lalu, konten kurikulum dalam buku teks dijabarkan dan dikembangkan dengan penetapan hasil belajar (learning outcomes), konsep teori dan latihan soal beserta aktivitas per topik.

Setiap tahun, sekolah menentukan jenis buku matematika sesuai kurikulum 2013 dan kebijakan berbahasa Inggris. Buku matematika kelas 8 berbahasa Inggris yang sesuai kurikulum 2013 dan sesuai kebijakan sekolah sulit didapat. Buku yang telah dipilih sekolah yang diteliti merupakan buku 
matematika impor dari Singapura yaitu New Syllabus Mathematics 2 dengan penyesuaian urutan bab diajar dengan pengaturan waktu dan tingkatan. Beberapa bab dari buku ini dapat dilewati maupun tidak dipelajari sama sekali. Hal ini berakibat siswa kelas 8 dapat membawa buku tingkat New Syllabus Mathematics 1 atau 3 untuk mengikuti pelajaran sesuai urutan ajar.

Buku pegangan pembelajaran perlu dirancang dan dibuat dengan spesifikasi yang diperlukan sekolah. Dalam merancang dan mengembangkan suatu produk atau program pendidikan dari sebuah mata pelajaran, dibutuhkan desain instruksional (Seel, Lehmann, Blumschein, \& Podolskiy, 2017). Produk secara terus menerus ditingkatkan, dibangun, diterapkan dan dievaluasi dalam pembelajaran (Brown \& Green, 2016). Penelitian yang berhubungan dengan desain intruksional ini merupakan jenis penelitian dan pengembangan. Dalam penelitian ini, produk atau prosedur yang dianalisis, didesain, dikembangkan, diujicobakan secara sistematis di lapangan, dievaluasi, dan disempurnakan sehingga efektif, berkualitas, dan memenuhi kriteria standar yang ditetapkan (Gall, Gall, \& Borg, 2003).

Berdasarkan masalah penggunaan buku pelajaran, survey kebutuhan siswa dan guru sekolah yang diteliti, dan hasil analisis kebutuhan, maka rumusan masalah yang didapat adalah sebagai berikut: 1) Bagaimana menemukan kebutuhan sekolah akan buku teks matematika, 2) Bagaimana mendesain buku teks yang sesuai kebutuhan sekolah, 3) Bagaimana mengembangkan buku teks dengan sumberdaya yang tersedia, 4) Bagaimana mengimplementasikan buku teksdalam kelas, 5) Bagaimana mengevaluasi buku teks sehingga menjadi lebih baik.

\section{KAJIAN PUSTAKA}

Buku teks adalah sebuah buku yang berhubungan dengan bidang ilmu tertentu, seperti matematika (Rahmawati I. Y., 2017: 90). Sebuah buku teks merupakan sebuah media ajar yang terdiri atas serangkaian materi dan aktivitas dimana guru dapat tentukan dalam pelajaran, sebagai pegangan belajar, dan disahkan oleh kementerian pendidikan (Radic-Bojanic \& Topalov, 2016: 139). Buku ini disusun secara sistematis berdasarkan urutan materi dan uraian dari sebuah mata pelajaran (Rahmawati I. Y., 2017: 107). Jadi buku teks adalah sebuah media ajar yang tersusun secara sistematis dan terdiri atas urutan materi dan uraian sebuah mata pelajaran yang disahkan oleh kementerian pendidikan.

Buku teks mempunyai pengaruh yang besar dalam kegiatan belajar mengajar yang dilakukan guru dan siswa (Amerian \& Khaivar, 2017: 524). Peranan buku ini sangat penting dalam menyampaikan pengetahuan dan keterampilan yang ada dalam kurikulum terhadap siswa dalam lingkungan belajar mengajar (You, Lee, \& Craig, 2019: 3). Buku teks dapat digunakan secara langsung di kelas secara eksplisit, secara tidak langsung dengan guru mengajarkan bahannya, atau tidak digunakan sama sekali untuk referensi saja (Matić \& Gracin, 2016). Selain itu, konten buku teks dapat mengandung materi lain di luar mata pelajaran seperti masalah hak asasi, gender, intoleransi, kekerasan, diskriminasi, agama, politik, dan isu lingkungan (UNESCO, 2016). Dengan demikian, buku teks mempunyai peranan yang besar yang dapat mempengaruhi pembelajar yang menggunakannya baik sisi bahan dalam kurikulum maupun di luar materi.

Isi atau konten sebuah buku teks mata pelajaran mengandung urutan materi yang termuat dalam kurikulum, dalam hal ini kurikulum 2013 di Indonesia. Kompetensi inti matematika sekolah menengah pertama dalam kurikulum 2013 meliputi kompetensi inti satu sikap spiritual, kompetensi inti dua sikap sosial, kompetensi tiga pengetahuan matematika, dan kompetensi inti empat keterampilan matematika (Kemendikbud, 2018). Dari kompetensi inti pengetahuan dan keterampilan diturunkan menjadi kompetensi dasar matematika kelas yang dipilih yaitu kelas 8. Isi dari buku teks matematika mengandung pengetahuan matematika dimana mengacu pada standar kurikulum sampai menjadi hasil capaian belajar (learning outcomes) (Gracin, 2018).

Sebagai buku matematika, buku teks ini memuat konten matematika yang terdiri atas unsur bilangan, aljabar, geometri, statistika dan pengukuran (Reyhani \& Izadi, 2018). Buku pelajaran yang baik mengandung pembelajaran berstruktur dengan pembukaan, daftar isi, daftar pustaka, konsep, contoh, tabel, gambar, tugas, dan evaluasi soal di tiap babnya (Pokrivcakova \& Pokrivcak, 2016). Selain itu, buku teks juga memuat bagian motivasi berupa gambar dan ilustrasi untuk menumbuhkan kreativitas pembelajar (Kasmaienezhadfard, 2015: 91). Dari penjabaran bagian konten tersebut di atas, maka konten buku pelajaran matematika berisikan bagian kurikulum, matematika, struktur, dan motivasi. 
Dalam menggunakan bahasa Inggris bagian grammar, pronunciation, dan vocabulary perlu diperhatikan terutama untuk penggunaan Inggris nyata bukan sekedar teks (Handayani, 2015, p. 337). Bagian grammar dan vocabulary pada buku teks seharusnya diterapkan secara seimbang dan sesuai dengan tingkat dan usia pembaca (Fatima, Shah, \& Sultan, 2015: 95). Bahan belajar memerlukan vocabulary yang cukup dan sesuai supaya pembaca sukses dalam menggunakannya (Nordlund, 2016, p. 60). Grammar dalam bahasa Inggris dapat mencakup tenses, nouns, pronous, adjectives, adverbs, gerund, infinitives, dan conjunctions (Azar \& Hagen, 2016). Untuk mengerti konten materi suatu pelajaran, dibutuhkan vocabulary akan arti kata-kata secara tepat dan luas (Alahmadi, Shank, \& Foltz, 2018, p. 20). Dengan demikian, bagian grammar dan vocabulary yang dipergunakan secara seimbang, tepat, dan sesuai dengan tingkat usia pembaca untuk sebuah buku pelajaran yang menggunakan bahasa Inggris sebagai pengantarnya.

Dari segi desain, factor yang mempengaruhi tata letak buku teks adalah warna (grafik, diagram, gambar, alat bantu ajar), kertas, dan hasil cetak (jenis huruf, gambar) (Hoshangabadwala, 2015). Sedangkan desain visual buku ajar mempunyai bagian seperti ukuran , ratio, warna, isi gambar, spread dari text, kepala judul, caption, tugas-tugas, foto, grafik (Behnke, 2016). Dari sebuah buku teks, bagian konten visual dapat berupa gambar, foto, diagram, grafik, tabel yang seharusnya digunakan untuk mengerti artinya (Guo, Wright, \& McTigue, 2018: 253). Hasil dari penelitian mengenai desain berdasarkan cover, background, dan warna mempengaruhi pembaca buku teks (Sullivan, 2015). Berdasarkan pendapat para ahli tersebut, maka dapat dinyatakan bahwa bagian desain dari sebuah buku teks mencakup cover, background, warna, gambar, grafik, proporsi, foto, tabel, jenis huruf yang digunakan.

Penelitian dan pengembangan merupakan sebuah penelitian yang diterapkan ketika mengembangkan bahan ajar untuk membantu pengajaran (Ibrahim, 2016: 5). Penelitian dan pengembangan adalah penelitian yang sistematik dan kreatif untuk meningkatkan kapasitas dari pengetahuan atau untuk membuat penerapan dari pengetahuan yang sudah ada (OECD, 2015). Penelitian ini mencakup bagian kurikulum, media dan teknologi, instruksi pembelajaran, pendidikan guru dan didaktik (Akker, 1999: 4). Penelitian dan pengembangan menggabungkan antara pengembangan yang menghasilkan produk atau prototype kursus dan penelitian berupa justifikasi yang terdiri atas argumentasi yang didukung analisis teori, data empiris, dan interpretasinya (Gravemeijer, 1998: 291). Jadi dapat disimpulkan bahwa penelitian dan pengembangan adalah penelitian sistematik dan kreatif yang menggabungkan antara pengembangan berupa produk pendidikan untuk membantu pengajaran dan penelitian berupa analisis terhadap produk pendidikan tersebut.

Model penelitian pengembangan yang digunakan secara umum meliputi: 1) Model Dick dan Carey dengan 10 langkah pembelajaran berupa: identifikasi tujuan pembelajaran, analisis instruksional, identifikasi perilaku awal, penulisan tujuan kinerja, membangun tes berkriteria, membangun strategi instruksi, membuat dan memilih materi pelajaran, membuat dan melaksanakan evaluasi formatif, merevisi pembelajaran dan melaksanakan evaluasi sumatif (Dick, Carey, \& Carey, 2015), 2) Model Borg dan Gall dengan sepuluh langkah penelitian dan pengembangan yang terdiri aas penelitian dan pengumpulan data, perencanaan, pengembangan draft produk awal, uji coba lapangan awal, uji coba produk utama, revisi produk, uji coba skala luas, revisi produk akhir (Gall, Gall, \& Borg, 2003), 3) Model ASSURE dengan tahap: analisis peserta didik, penetapan tujuan dan standar, seleksi material, utilisasi material, partisipasi pembelajar, evaluasi dan revisi (Sundayana, herman, Dahlan, \& Prahmana, 2017), 4) Model SAM dengan tahap: fase persiapan, fase desain berulang, dan fase pengembangan berulang (Jung \& Kim, 2019),

Model pengembangan yang digunakan adalah ADDIE mempunyai kelebihan yaitu lebih sederhana, teratur, dan banyak dipakai dalam membuat program maupun produk pembelajaran secara efektif dan tervalidasi oleh ahli (Piskurich, 2015). Model ini juga menjadi dasar pengembangan model lain seperti model Dick dan Carey dan modifikasinya PADDIE. Namun model ADDIE ini mempunyai kelemahan seperti waktu yang diperlukan lama dan terlalu menekankan konten buka pengalaman belajar (Sites \& Green, 2014). Kelemahan ini diatasi dengan persiapan yang matang dan penambahan komponen yang kurang seperti pengalaman belajar. ADDIE juga merupakan model desain instruksional yang membangun materi maupun produk berdasarkan kinerja. Hubungan antar tahap pada ADDIE dilihat pada diagram di bawah ini. 


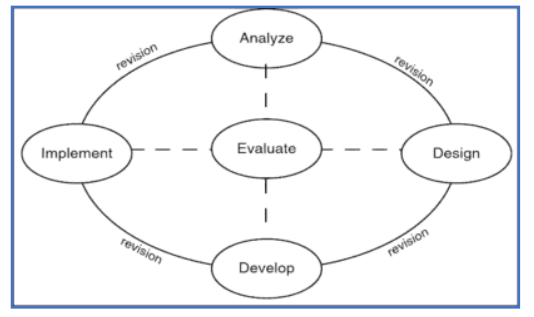

Gambar 1. Diagram Tahapan ADDIE (Branch, 2009)

Model ADDIE diterapkan pada penelitian dan pengembangan terhadap buku teks kelas 7 SMP dengan mata pelajaran matematika topik himpunan (Fatikhah \& Izzati, 2015). Buku tersebut divalidasi oleh ahli yang merupakan guru sekolah dan diimplementasi dan diuji melalui pre-test dan post-test. Penelitian dan pengembangan menggunakan model ADDIE dilakukan terhadap buku ajar dari mahasiswa calon guru dengan pelajaran matematika statistika elementer (Makur \& Fed, 2018). Penelitian ini menggunakan analisis kebutuhan, ujian, dan validasi ahli terhadap produk yang direvisi sebanyak 3 kali dengan kriteria kevalidan, kepraktisan, dan efek potensial. Penelitian yang selaras dilakukan terhadap SMA dengan produk buku saku matematika topik trigonometri (Cahyono, Tsani, \& Rahma, 2018). Buku ini divalidasi dengan kriteria ketercakupan materi, muatan pendidikan karakter, dan kelayakan sebagai media melalui tiga tahap dan diuji dengan pre-test dan post-test pada tiap tahapnya. Sebuah buku SD matematika dengan metode Muvizu diteliti dan dikembangkan dengan model ADDIE (Azizah, 2016). Buku ini dianalisis kebutuhan, divalidasi ahli pengembangan, media, dan materi pembelajaran matematika, diimplementasikan di kelas SD dengan ujian, dan dievaluasi dengan revisi pada tiga tahap. Penelitian sejenis yang menggunakan model ADDIE dilakukan terhadap buku matematika kelas 8 SMP (Kharisma \& Asman, 2018). Buku ini menggunakan desain standar kurikulum 2013, dianalisis dengan penilaian ahli, penilaian guru dan siswa, observasi, dan test dengan fokus pada pemecahan masalah dan prestasi belajar matematika. Maka secara garis besar, penelitian dan pengembangan menggunakan model ADDIE melalui tahap analisis yang menggunakan analisis kebutuhan, tahap desain dengan standar kurikulum yang digunakan, tahap pengembangan dengan validasi ahli dengan kriteria, tahap implementasi dengan pengajaran di kelas disertai ujian, dan tahap evaluasi dengan revisi produk minimal tiga tahap.

Untuk itu, disusun kerangka berpikir penelitian yang dimulai dari adanya masalah bahan ajar yang ada di kelas yaitu menggunakan buku teks impor New Syllabus Mathematics 2 yang diikuti dengan peraihan informasi melalui survey kebutuhan. Survey kebutuhan dianalisis dalam bentuk analisis kebutuhan yang merekomendasikan akan pembuatan buku Matematika Kelas 8 semester satu dengan berbahasa Inggris dan sesuai kurikulum 2013. Kemudian buku tersebut didesain dengan isi mengikuti kurikulum 2013. Lalu produk tersebut dikembangkan dengan acuan validasi ahli berdasarkan kriteria konten, bahasa, dan desain. Buku diimplementasikan dengan diajarkan pada siswa kelas 8 dan diujikan dengan pre-test dan post-test. Dan buku dievaluasi dengan revisi bertahap yang kembali dirancang ulang dengan tingkatan prototype mulai dari individual, kelompok kecil, dan kelompok besar sampai menjadi produk akhir.

Diagram berikut merupakan kerangka berpikir penelitian:

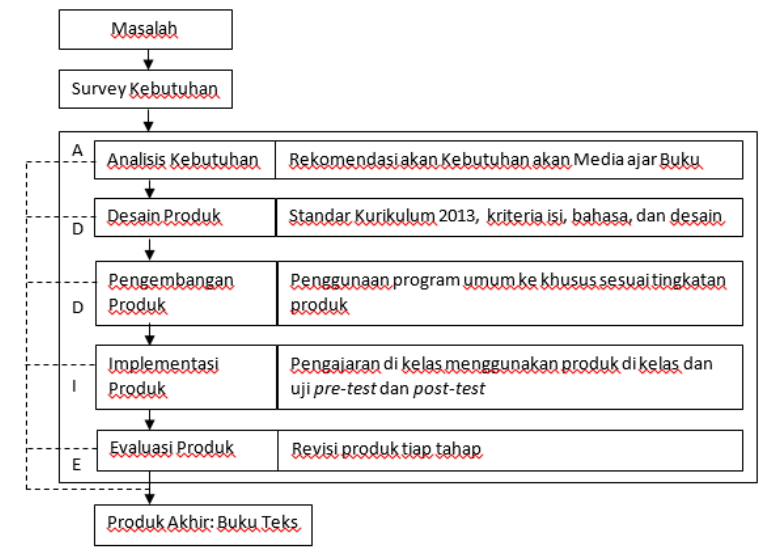

Gambar 2. Kerangka Berpikir Penelitian

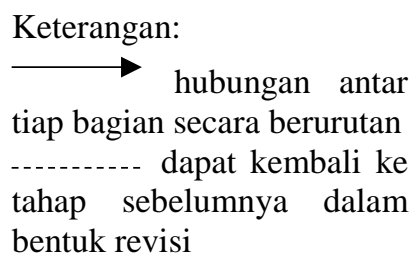

\section{Keterangan:}

$\longrightarrow$ hubungan antar tiap bagian secara berurutan tahap sebelumnya dalam bentuk revis 


\section{METODE PENELITIAN}

Metode penelitian yang digunakan adalah penelitian dan pengembangan atau Research and Development dengan model pengembangan ADDIE. Penelitian ini diadakan di sebuah sekolah swasta berlokasi di Jakarta Barat, Indonesia. Subyek penelitian meliputi 96 siswa kelas 8 dan 10 guru. Tahapan pengembangan mengikuti tahap ADDIE yaitu: 1) Tahap Analyze, 2) Design, 3) Development, 4) Implement, 5) Evaluate

Instrumen penelitian yang digunakan adalah: analisis kebutuhan, validasi ahli dan ujian pre-test beserta post-test. Survey dilakukan sebelum analisis kebutuhan untuk mendapat informasi awal mengenai kebutuhan bahan ajar. Untuk menvalidasi media ajar seperti buku teks, disusun indikator validasi yang berdasarkan isi, bahasa, dan desain. Validasi ini dilakukan oleh 3 guru mata pelajaran yaitu matematika bagian konten, bahasa Inggris bagian bahasa, dan kesenian bagian desain. Kriteria konten terdiri atas bagian kurikulum, matematika, struktur, dan motivasi. Kriteria bahasa Inggris terdiri atas bagian grammar dan vocabulary. Kriteria bagian desain terdiri atas cover, background, warna, gambar, grafik, proporsi, foto, tabel, jenis huruf. Rubrik penilaian tiap konten digunakan sebagai standar penilaian dengan kriteria yang ditetapkan bersama para ahli dan peneliti.

Untuk menentukan keefektifan dari pre-test dan post-test dari kelompok yang diuji, digunakan statistik deskriptif berupa rata-rata ujian dan $\mathrm{N}$-gain dengan rumus: $\mathrm{N}$-gain $=($ post-test-pre-test $)$ : (maksimum -pre-test). Kriteria $\mathrm{N}$-gain menggunakan score: tinggi bila $\mathrm{N}$ di atas atau sama dengan 0.7 , sedang bila di bawah 0.7 dan di atas atau sama dengan 0.3, dan rendah bila di bawah 0.3 (Hake, 1998, p. 65).

Data dikumpulkan dengan melalui survey, lembar validasi ahli dan ujian pre-test dan post-test dari prototype 1 , prototype 2 , prototype 3 dan produk akhir.

\section{HASIL PENELITIAN}

Pada tahap analisis, diadakan survey kebutuhan dilakukan terhadap 24 siswa kelas 8 dan 10 guru yang terlihat pada tabel 1 .

Tabel 1. Hasil Survey Kebutuhan Bahan Ajar

\begin{tabular}{|c|c|c|c|c|}
\hline No. & Pertanyaan & Jawaban & Siswa & Guru \\
\hline \multirow[t]{2}{*}{1} & \multirow{2}{*}{$\begin{array}{l}\text { Apa judul Buku Ajar Matematika yang dipakai } \\
\text { sekarang? }\end{array}$} & New Syllabus Mathematics 2 & 22 & 4 \\
\hline & & Jawaban lain & 2 & 6 \\
\hline \multirow[t]{3}{*}{2} & \multirow[t]{3}{*}{ Apakah kendala buku pegangan tersebut? } & Fisik yang berat dan tebal & 15 & 0 \\
\hline & & Materi tidak sesuai kurikulum & 2 & 10 \\
\hline & & Jawaban lain & 7 & 0 \\
\hline \multirow[t]{2}{*}{3} & \multirow[t]{2}{*}{ Apakah materi sesuai kurikulum pemerintah? } & Sesuai & 12 & 4 \\
\hline & & Tidak sesuai & 10 & 6 \\
\hline \multirow[t]{2}{*}{4} & \multirow[t]{2}{*}{ Bentuk bahan ajar apa yang diinginkan? } & Buku teks & 8 & 4 \\
\hline & & Jawaban lain & 14 & 6 \\
\hline \multirow[t]{2}{*}{5} & \multirow[t]{2}{*}{ Hal apa saja yang tertera dalam isi bahan ajar itu? } & Tujuan, konsep, aktivitas, latihan & 24 & 24 \\
\hline & & Jawaban lain & 0 & 0 \\
\hline
\end{tabular}

Analisis kebutuhan menggunakan hasil survey tersebut dengan menyelidiki buku pegangan saat itu yaitu New Syllabus Mathematics 2 dalam hal konten dan fisik. Hasil analisis kebutuhan bagian konten, didapat jumlah yang diajar buku New Syllabus Mathematics 2 sebanyak 13 topik sedangkan kurikulum 2013 revisi sebanyak 10 topik dalam satu tahun ajaran. Secara fisik, buku New Syllabus Mathematics 2 mempunyai berat 300 gram, 420 halaman, dan ukuran kertas kwarto. Analisis kebutuhan juga memuat informasi mengenai kebijakan sekolah yang menggunakan buku pegangan matematika dalam bahasa Inggris.

Pada tahap desain, dipersiapkan sumberdaya berupa materi, ahli, jadwal, dan program untuk merancang produk dengan standar yang sesuai kurikulum dan kebutuhan. Materi diambil dari berbagai sumber buku matematika dan disesuaikan dengan kurikulum 2013 revisi kelas 8 semester satu. Topik yang diambil mulai dari barisan dan deret, koordinat geometri, relasi dan fungsi, persamaan garis lurus, dan persamaan linear 2 variabel. Penyusunan lembar validasi dan rubrik penilaiannya dilakukan dengan 
diskusi bersama para ahli yang diminta kesediaannya. Penyusunan lembar ujian dipersiapkan sesuai dengan tahap produk dan kelompok yang diuji. Jadwal penelitian disusun dalam waktu 1 tahun untuk penelitian dan pengembangan produk tersebut.

Pada tahap pengembangan, produk dikembangkan dengan mengisi dan meningkatkan materi dari segi konten, isi, dan desain. Prototype satu menggunakan program Microsoft Word dalam pengolahannya. Produk tahap ini berbentuk draft booklet seperti pada gambar 1. Secara umum konten berisi ringkasan materi dan latihan soal, bahasa Inggris yang grammar dan vocabulary yang belum direvisi, dan penggunaan kata-kata yang lebih banyak dengan sedikit gambar di bagian desain.

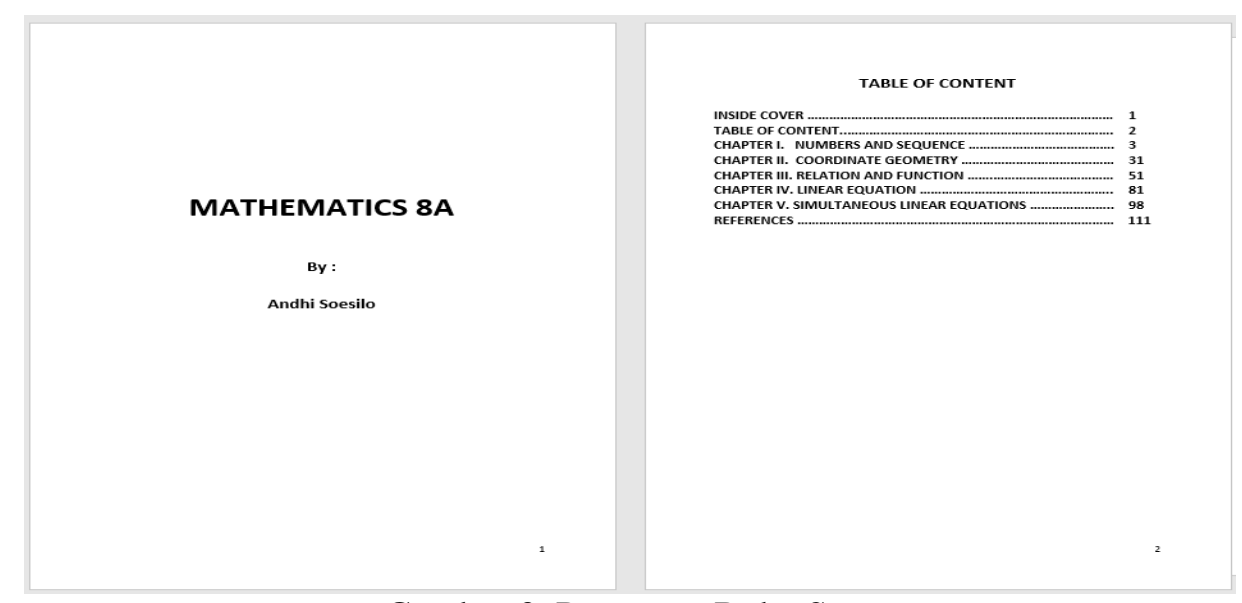

Gambar 3. Prototype Buku Satu

Hasil validasi ahli prototype satu dapat dilihat pada tabel berikut:

Tabel 2. Hasil Validasi Ahli Prototype 1

\begin{tabular}{llcccc}
\hline No. & \multicolumn{1}{c}{ Kriteria } & Nilai & $\begin{array}{c}\text { Nilai } \\
\text { Maks. }\end{array}$ & $\begin{array}{c}\text { Persentase } \\
\text { Validasi }\end{array}$ & $\begin{array}{l}\text { Keputusan } \\
\text { Validasi }\end{array}$ \\
\hline 1 & Konten & 45 & 85 & $52.9 \%$ & Kurang valid \\
\hline 2 & Bahasa Inggeris & 12 & 45 & $26.7 \%$ & Tidak Valid \\
\hline 3 & Desain & 30 & 60 & $50 \%$ & Kurang Valid \\
\hline & Total Score & 87 & 190 & $45.8 \%$ & Kurang Valid \\
\hline
\end{tabular}

Keterangan : Rentang nilai 0\%-41\% tidak valid, $41 \%-60 \%$ kurang valid,

$61 \%-80 \%$ cukup valid, dan $81 \%-100 \%$ sangat valid.

Gambar 3 menunjukkan salah satu halaman dari prototype buku kedua menggunakan program Adobe Indesign dalam pengolahannya.

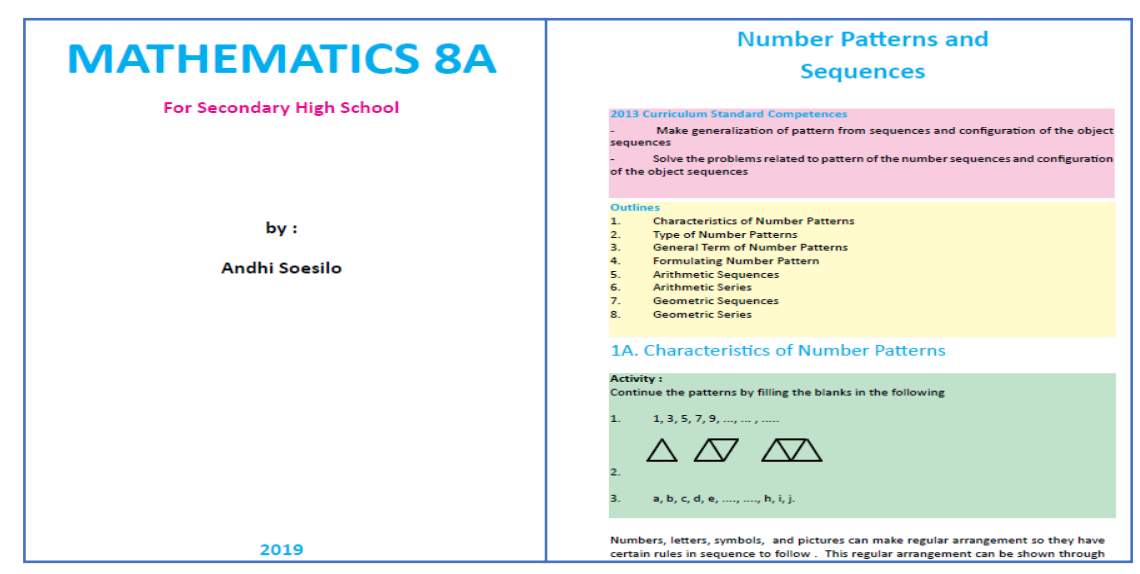

Gambar 4. Prototype Buku 2 
Produk tahap ini berbentuk buku yang dijilid dengan kertas HVS A4 tanpa cover berwarna. Pada prototype dua ini terjadi penambahan bagian konten seperti struktur dan jenis huruf, bagian bahasa seperti perbaikan grammar dan vocabulary, dan bagian desain seperti penambahan warna dan gambar.

Hasil validasi ahli prototype dua dapat dilihat pada tabel berikut:

Tabel 3. Hasil Validasi Ahli Prototype 2

\begin{tabular}{llcccc}
\hline No. & Kriteria & Nilai & Nilai Maks. & $\begin{array}{c}\text { Persentase } \\
\text { Validasi }\end{array}$ & Keputusan Validasi \\
\hline 1 & Konten & 60 & 85 & $70.6 \%$ & Cukup Valid \\
\hline 2 & Bahasa Inggeris & 20 & 45 & $44.4 \%$ & Kurang Valid \\
\hline 3 & Desain & 37 & 60 & $61.7 \%$ & Cukup Valid \\
\hline & Total Score & 117 & 190 & $61.6 \%$ & Cukup Valid \\
\hline
\end{tabular}

Keterangan : Rentang nilai 0\%-41\% tidak valid, 41\%-60\% kurang valid,

$61 \%-80 \%$ cukup valid, dan $81 \%-100 \%$ sangat valid.

Prototype tiga menggunakan program Adobe Indesign dalam pengolahannya. Produk tahap berbentuk buku yang dijilid dengan kertas HVS A4 dengan cover berwarna. Pada prototype tiga ini ditambahkan komponen learning outcomes, refleksi dan ujian bab pada bagian konten, perbaikan grammar dan typo pada bagian bahasa, dan perbaikan layout beserta proporsi gambar pada bagian desain.

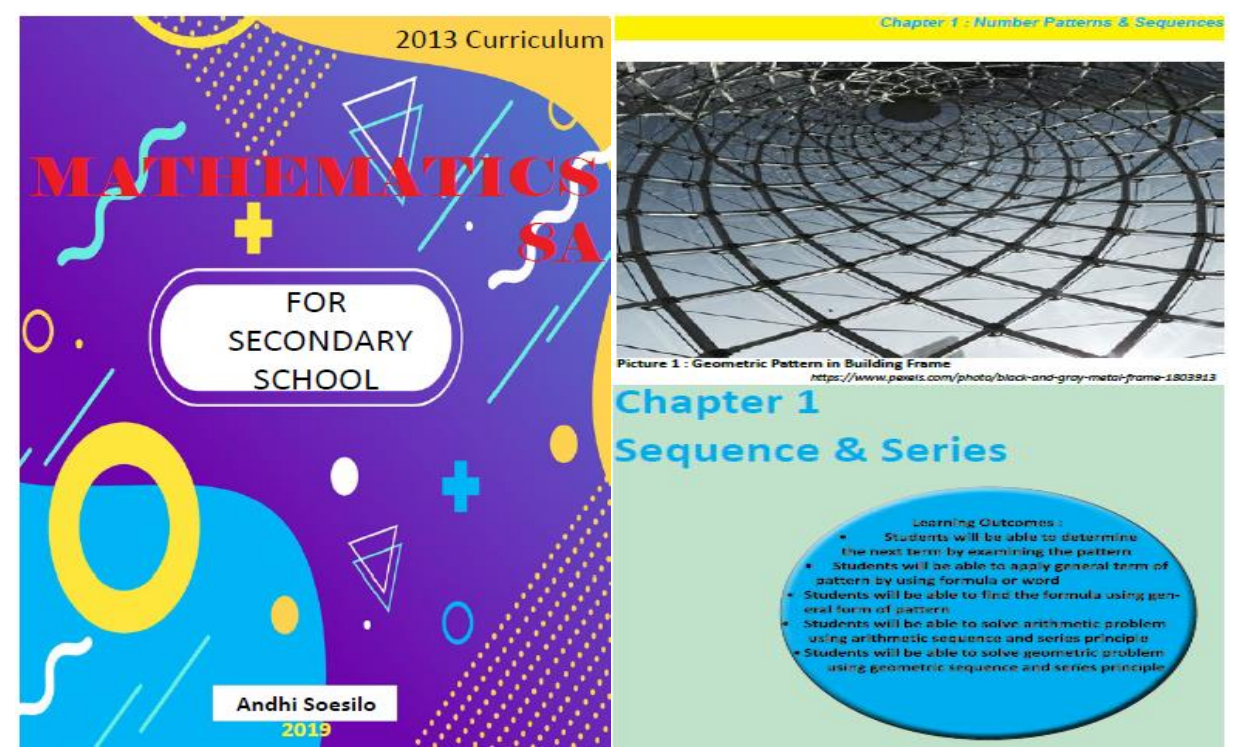

Gambar 5. Prototype Buku Tiga

Hasil validasi ahli prototype tiga dapat dilihat pada tabel berikut:

Tabel 4. Hasil Validasi Ahli Prototype 3

\begin{tabular}{llcccl}
\hline No. & \multicolumn{1}{c}{ Kriteria } & Nilai & Nilai Maks. & $\begin{array}{c}\text { Persentase } \\
\text { Validasi }\end{array}$ & Keputusan Validasi \\
\hline 1 & Konten & 66 & 85 & $77.6 \%$ & Cukup Valid \\
\hline 2 & Bahasa Inggeris & 28 & 45 & $62.2 \%$ & Cukup Valid \\
\hline 3 & Desain & 47 & 60 & $78.3 \%$ & Cukup Valid \\
\hline & Total Score & 141 & 190 & $74.2 \%$ & Cukup Valid \\
\hline
\end{tabular}

Keterangan : Rentang nilai 0\%-41\% tidak valid, 41\%-60\% kurang valid,

$61 \%-80 \%$ cukup valid, dan $81 \%-100 \%$ sangat valid.

Pada tahap implementasi, produk diajarkan ke kelas dengan tampilan presentasi versi $p d f$-nya di kelas yang dituju. Ujian pre-test dilakukan sebelum implementasi dan ujian post-test dilakukan setelah implementasi produk tersebut. Berikut merupakan hasil pre-test dan post-test dari tiap kelompok yang diujikan: 
Pengembangan Buku Teks Matematika Kelas 8 Dengan Model ADDIE

(Andhi Soesilo, Ashiong Parhehean Munthe)

Tabel 5. Hasil Pre-test dan Post-test Tiap Kelompok

\begin{tabular}{llll}
\hline \multicolumn{1}{c}{ Uji } & Pre-test & Post-test & N-gain \\
\hline Satu-satu & 63 & 68.56 & -0.003 \\
\hline Kelompok Kecil & 35.17 & 65.7 & 0.445 \\
\hline Uji Lapangan & 50.63 & 72.25 & 0.436 \\
\hline
\end{tabular}

Pada tahap evaluasi, setiap tahap produk direvisi dengan kembali ke tahap sebelumnya jika masih terdapat kekurangan dari validasi maupun hasil ujiannya. Setelah tiga tahap, produk akhir dihasilkan dengan penambahan kurikulum pada bagian konten, perbaikan grammar dan typo di bagian bahasa, dan penambahan icon di bagian desain. Produk akhir mempunyai judul buku Mathematics Grade 8 Semester 1 dengan 140 halaman dan massanya 200 gram yang terlihat pada gambar 5.

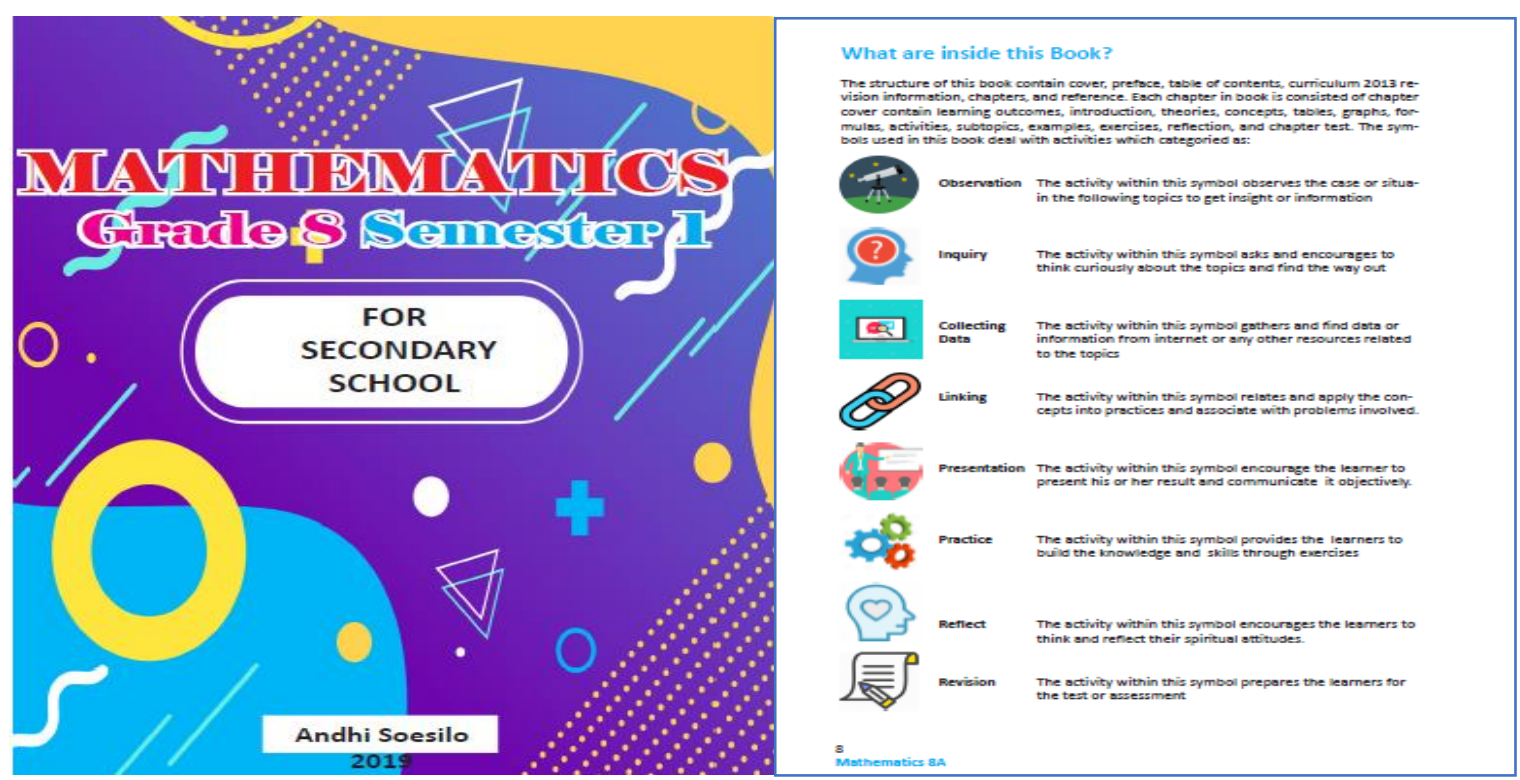

Gambar 6. Produk Akhir Buku

Tabel 6 menunjukkan hasil validasi ahli pada produk akhir.

Tabel 6. Hasil Validasi Ahli Produk Akhir

\begin{tabular}{llcccl}
\hline No. & \multicolumn{1}{c}{ Kriteria } & Nilai & Nilai Maks. & $\begin{array}{c}\text { Persentase } \\
\text { Validasi }\end{array}$ & Keputusan Validasi \\
\hline 1 & Konten & 71 & 85 & $83.5 \%$ & Sangat Valid \\
\hline 2 & Bahasa Inggeris & 37 & 45 & $82.2 \%$ & Sangat Valid \\
\hline 3 & Desain & 57 & 60 & $95.0 \%$ & Sangat Valid \\
\hline & Total Score & 165 & 190 & $86.8 \%$ & Sangat Valid \\
\hline
\end{tabular}

Keterangan : Rentang nilai 0\%-41\% tidak valid, 41\%-60\% kurang valid,

$61 \%-80 \%$ cukup valid, dan $81 \%-100 \%$ sangat valid.

Pada evaluasi produk akhir, diadakan ujian sumatif terhadap seluruh kelas 8 sebanyak 96 siswa dengan pre-test dan post-test. Hasil ujian sumatif adalah sebagai berikut:

Tabel 7. Hasil Ujian Sumatif Kelas 8

\begin{tabular}{llll}
\hline Kelas & Pre-test & Post-test & N-gain \\
\hline $8 \mathrm{~B}$ & 45.29 & 67.79 & 0.363 \\
\hline 8C & 49.25 & 65.67 & 0.362 \\
\hline 8D & 43.79 & 60.5 & 0.354 \\
\hline 8E & 52 & 68.2 & 0.395 \\
\hline Rata-rata & 47.58 & 65.54 & 0.368 \\
\hline
\end{tabular}




\section{PEMBAHASAN}

Dari hasil analisis kebutuhan, didapat bahwa buku New Syllabus Mathematics 2 menggunakan kertas kwarto dan ukuran buku bacaan umum berukuran A5. Jadi buku ini lebih besar dan berat karena mempunyai 420 halaman dan massa 300 gram. Penelitian sejenis yang mendukung akan pentingnya fisik berupa kertas dan ukurannya dilakukan pada tahap analisis kebutuhan pada buku SMK pelajaran bahasa Inggris (Cahyati \& Rizkiani, 2017, p. 48). Sedangkan topik dari New Syllabus Mathematics 2 hanya berbeda 3 topik daripada kurikulum 2013 dalam setahun, dan pada semester satu, hanya 3 topik dari New Syllabus Mathematics 2 yang sesuai dengan kurikulum 2013. Hal ini menyebabkan siswa kelas 8 dapat membawa buku New Syllabus Mathematics 1 dan 3 untuk mengikuti pelajaran agar sesuai dengan kurikulum 2013 yang diberlakukan di sekolah tersebut.

Analisis kebutuhan merekomendasikan pilihan mencari buku teks matematika berbahasa Inggris dengan kurikulum 2013 di pasaran atau membuat sendiri buku teks sesuai dengan kurikulum 2013 dan kebutuhan sekolah. Mengenai penggunaan buku dalam bahasa Inggris, ditemukan penelitian serupa pada tingkat perguruan tinggi menunjukkan hasil yang baik secara praktis dengan diterapkannya metode Collaborative Learning (Deswita \& Niati, 2018, p. 125). Hal ini menunjukkan penggunaan buku matematika berbahasa Inggris dapat diterapkan di sekolah dengan metode pengajaran yang tepat. Penelitian selaras mengenai analisis kebutuhan menyelidiki pengembangan buku sekolah yang dilakukan terhadap buku kurikulum KTSP yang tidak sesuai dengan permintaan akan kurikulum 2013 (Kharisma \& Asman, 2018, p. 39).

Desain dari buku Matematika kelas 8 semester 1 ini menggunakan kurikulum 2013 sebagai acuannya. Konsep teori, rumus, dan soal-soal diambil dari kombinasi berbagai buku matematika yang telah menggunakan kurikulum tersebut seperti buku Matematika 2A (Adinawan, 2017) dan soal-soal yang diadaptasi dari buku New Syllabus Mathematics $27^{\text {th }}$ edition (Seng, Yee, Yeo, \& Chow, 2014). Desain buku didasari oleh kriteria konten, bahasa, dan desain yang menjadi acuan validasi ahli dalam menilainya. Hal ini serupa dengan penelitian yang diadakan untuk mengevaluasi sebuah buku teks bahasa Inggris untuk SMA yang berdasarkan kriteria demikian (Papajani, 2015). Bagian konten berupa kurikulum dan bahasa, struktur berupa layout atau desain, bimbingan, dan tugas penilaian yang disampaikan dalam buku pelajaran akuntansi (Ngwenya \& Arek-Bawa, 2019) merupakan kriteria yang selaras dengan temuan dari penelitian ini. Temuan lain didapat dari evaluasi sebuah buku SD kelas 6 yang membahas konten buku yang memuat kurikulum, fisik buku yang memuat struktur dan desain, dan penggunaan bahasa pengantar (Momand, Sugunabalan, Ibrahim, \& SC, 2019).

Produk dikembangkan dari prototype satu yang menggunakan Microsoft Word yang menghasilkan berkas teks dengan sedikit gambar. bahasa, dan desain. Penelitian sejenis menggunakan program Microsoft word sebagai awal pengembangan buku teks geografi (Suryani, Ruhimat, \& Ningrum, 2015). Produk ini memerlukan sumberdaya sedikit dan mudah dibuat sehingga cocok untuk kalangan terbatas yang membutuhkan pegangan belajar yang ringkas, sederhana, dan murah. Untuk penggunaan lebih luas dan umum, prototype satu tidak dapat digunakan karena kurang valid menurut validasi dari guru. Penelitian sejenis menggunakan program Microsoft Word dilakukan terhadap membuat buku saku pelajaran matematika ekonomi yang praktis (Pramika \& Widalismana, 2018). Implementasi prototype satu pada saat awal pelajaran semester satu tahun 2018. Rata-rata ujian pre-test dan post-test di atas 60 dan nilai $\mathrm{N}$-gain -0.003 menunjukkan implementasi produk turun dan sangat rendah dengan hampir tidak ada peningkatan. Produk direvisi kembali dengan perubahan program karena keterbatasan Microsoft Word dalam menangani desain buku, hasil validasi ahli dan test yang kurang baik.

Prototype dua menggunakan Adobe Indesign yang biasanya digunakan dalam mendesain buku. Produk ini lebih baik daripada prototype satu dengan perubahan konten dengan struktur lebih baik, bahasa dengan perbaikan grammar, dan desain dengan penambahan warna. Penelitian dan pengembangan serupa menggunakan Adobe Indesign sebagai program untuk membuat buku panduan mentor bagi kegiatan anti rokok (Heryuliandini, Situmorang, \& Suprayekti, 2018). Prototype dua ini dapat digunakan di lingkungan sekolah sendiri dengan bentuk yang ringkas, sederhana, dan tidak menggunakan banyak warna. Untuk penggunaan umum dan luas, prototype dua ini kurang baik untuk digunakan karena masih kurang valid menurut para ahli. Implementasi prototype dua ini pada saat pertengahan semester satu bulan Oktober tahun 2018 dengan 2 bab yang diuji pada kelompok kecil 
Pengembangan Buku Teks Matematika Kelas 8 Dengan Model ADDIE

(Andhi Soesilo, Ashiong Parhehean Munthe)

pada salah satu kelas terpilih. Rata-rata ujian pre-test kurang baik dan meningkat saat post-test dengan $N$-gain mencapai 0.445 yang sedang tingkat kriterianya.

Prototype tiga merupakan revisi dari prototype dua dengan penambahan komponen kurikulum

2013, perbaikan grammar dan vocabulary, dan penambahan cover berwarna beserta proporsi gambar dan tulisan. Menurut validasi para ahli, prototype tiga yang dibuat dengan Adobe Indesign ini valid untuk penggunaan di kelas. Penelitian serupa menggunakan validasi ahli dan pengembangan buku menggunakan Adobe Indesign pada buku saku biologi (Suryanda, Azrai, \& Julita, 2019). Implementasi dan uji lapangan dilakukan saat akhir semester satu bulan November tahun 2018 di salah satu kelas terpilih yang berbeda dengan uji kelompok kecil. Hasil pre-test dan ke post-test dengan $\mathrm{N}$-gain mencapai 0.436 yang berkategori sedang peningkatannya.

Produk akhir adalah kelanjutan dari prototype tiga yang dibuat dengan Adobe Indesign dan disempurnakan dengan revisi minor di bagian konten, bahasa dan desain. Menurut validasi para ahli, produk ini sangat valid dan layak untuk dijadikan buku pegangan sekolah. Implementasi dilakukan di empat kelas 8 di awal semester dua bulan Februari tahun 2019. Penelitian yang serupa dengan tahapan prototype sampai produk akhir dilakukan terhadap anak usia dini dengan produk buku bergambar (Halim \& Munthe, 2019). Keseluruhan kelas 8 yang diajar menunjukkan N-gain rata-rata sebesar 0.368 yang sedang peningkatannya dari hasil pre-test dan post-test uji sumatif. Penelitian selaras yang menggunakan uji sumatif untuk tahap evaluasi yang menggunakan ADDIE pada pengembangan buku pelajaran geografi desa-kota SMA (Hadi \& Agustina, 2016).

\section{SIMPULAN DAN SARAN}

Kesimpulan yang didapat dari penelitian dan pengembangan buku ini adalah sebagai berikut:

1. Dengan diadakannya analisis kebutuhan, terdapat kebutuhan sekolah akan media pembelajaran buku teks yang berbahasa Inggris, praktis secara ukuran, dan sesuai kurikulum 2013 yang disebabkan buku pegangan yang ada kurang sesuai dengan kebutuhan tersebut.

2. Desain dilakukan terhadap rancangan buku berdasarkan standar kurikulum 2013 kelas 8 semester satu dan kriteria atas konten, bahasa, dan desain yang menjadi acuan validasi ahli.

3. Pengembangan buku menggunakan program yang berubah dari umum seperti Microsoft Word menjadi program khusus pengeditan buku seperti Adobe Indesign. Dalam proses ini, setiap tahap produk berupa prototype 1, prototype 2, dan prototype 3 yang divalidasi oleh para ahli dari segi konten, bahasa, dan desain.

4. Implementasi melibatkan pengajaran di kelas menggunakan buku tersebut dan diujikan dengan pre-test maupun post-test. Hasilnya menunjukkan peningkatan keefektifan mulai dari prototype 1 yang kurang efektif dari test yang mempunyai $N$-gain -0.003 , prototype 2 yang mempunyai $N$-gain 0.445 , prototype 3 yang mempunyai $N$-gain 0.436 .

5. Evaluasi dilakukan setelah tahap implementasi dengan merevisi prototype sehingga menjadi lebih baik dari sebelumnya. Produk akhir diuji dengan test sumatif yang mempunyai $N$-gain rata-rata 0.368 . Jadi dihasilkan produk akhir berupa buku matematika kelas 8 semester satu yang berbahasa Inggris, sesuai kurikulum 2013, tervalidasi, dan secara fisik tidak berat dan tebal.

Saran implementasi dari penelitian pengembangan ini berupa perlunya waktu yang cukup untuk pengadaan penelitian karena membutuhkan persiapan yang matang dan jadwal pelajaran yang tidak berulang dalam satu tahun. Hal ini dialami oleh penelitian selaras yang membutuhkan waktu di bagian desain dan pengembangan buku ajar dan guru pelajaran IPA (Sar'iyyah, Abdullah, \& Novianti, 2018). Saran penelitian selanjutnya berupa pengembangan buku teks menjadi buku digital yang dapat memuat fitur multimedia dan terkoneksi dengan internet. Salah satunya dilakukan oleh penelitian yang mengembangkan buku digital matematika dengan program 3D Pageflip (Indariani, Ayni, Pramuditya, \& Noto, 2019) dan video pembelajaran (Dewi \& Rimpiati, 2016). 


\section{DAFTAR PUSTAKA}

Adinawan, M. C. (2017). Matematika 2A. Jakarta: Erlangga.

Akker, J. v. (1999). Principles and Methods of Development Research. In J. v. Akker, R. M. Branch, K. Gustafson, N. Nieveen, \& T. Plomp, Design Approaches and Tools in Education and Training (pp. 1-14). Springer Science Business Media Dordrecht.

Alahmadi, A., Shank, C., \& Foltz, A. (2018). Vocabulary Learning Strategies and Vocabulary Size: Insights from Educational Level and Learner Styles. Vocabulary Learning and Instruction Vol $7(1), 1-30$.

Amerian, M., \& Khaivar, A. (2017). Textbook Selection, Evaluation and Adaption. International Journal of Language Learning and Applied Linguistics World, 523-533.

Azar, B. S., \& Hagen, S. A. (2016). Understanding and Using English Grammar. New York: Longman.

Azizah, S. (2016). Pengembangan Media Pembelajaran Matematika Berbasis Muvizu di Kelas 2 Sekolah Dasar. JKPM Vol 1 (2), 180-192.

Behnke, Y. (2016). How textbook design may influence learning with geography textbooks. Nordidactica-Journal of Humanities and Social Science Education, 38 - 62.

Branch, R. M. (2009). Instructional Design : ADDIE Approach. New York: Springer.

Brown, A. H., \& Green, T. D. (2016). The Essential of Instructional Design. New York: Routledge.

Cahyati, S. S., \& Rizkiani, S. (2017). Analisis Kebutuhan Siswa dalam Materi Buku Teks Bahasa. Jurnal Ilmiah UPT P2M STKIP Siliwangi Vol 5 (1), 39-51.

Cahyono, B., Tsani, D. F., \& Rahma, A. (2018). Pengembangan Buku Saku Matematika Berbasis Karakter pada Materi Trigonometri. Phenomenon Vol 8 (2), 72-86.

Deswita, H., \& Niati, B. (2018). Pengajaran Buku Ajar Bahasa Inggris Matematika Berbasis Collaborative Learning untuk Mahasiswa Pendidikan Matematika. JURNAL MathEdu (Mathematic Education Journal) Vol 1 (3), 118-126.

Dewi, L. I., \& Rimpiati, N. (2016). Efektivitas Penggunaan Media Pembelajaran Video Interaktif dengan Seting Diskusi Kelompok Kecil untuk Meningkatkan Keterampilan Berpikir Kritis Anak Usia Dini. JEPUN (Jurnal Pendidikan Universitas Dhyana Pura) Vol 1 (1), 31-46.

Dick, W., Carey, L., \& Carey, J. O. (2015). The Systematic Design of Instruction 8th edition. Boston: Pearson.

Fatikhah, I., \& Izzati, N. (2015). Pengembangan Modul Pembelajaran Matematika Bermuatan Emotion Quotient pada Pokok Bahasan Himpunan. EduMa Vol. 4 (2) , 46-61.

Fatima, G., Shah, S. K., \& Sultan, H. (2015). Textbook Analysis and Evaluation of 7th \& 8th Grade in Pakistani Context. International Journal of English Language Teaching Vol 3 (4), 79-97.

Gall, M., Gall, J. P., \& Borg, W. (2003). Educational Research : An Introduction 7th edition. Boston: Pearson Education.

Gracin, D. G. (2018). Requirements in Mathematics Textbooks: a Five Dimensional Analysis of Textbook Exercises and Examples. International Journal of Mathematical Education in Science and Technology, 1003 - 1024.

Gravemeijer, K. (1998). Developmental Research as a Research Method. In A. Sierpinska , \& J. Kilpatrick, Mathematics Education as a Research Domain: A Search for Identity (pp. 277295). New York: Springer Science+Business Media.

Guo, D., Wright, K. L., \& McTigue, E. M. (2018). A Content Analysis of Visuals in Elementary School Textbooks. The Elementary School Journal Vol 119 (2), 244-269.

Hadi, H., \& Agustina, S. (2016). Pengembangan Buku Ajar Geografi Desa-Kota Menggunakan Model ADDIE. Jurnal Educatio Vol 11 (1), 90-105. 
Pengembangan Buku Teks Matematika Kelas 8 Dengan Model ADDIE

(Andhi Soesilo, Ashiong Parhehean Munthe)

Hake, R. R. (1998). Interactive-engagement versus Traditional Methods: A Six-thousand-student Survey of Mechanics Test Data for Introductory Physics Courses. American Association of Physics Teachers, 64-74.

Halim, D., \& Munthe, A.P. (2019). Dampak Pengembangan Buku Cerita Bergambar Untuk Anak Usia Dini. Scholaria: Jurnal Pendidikan dan Kebudayaan Vol 9 (3), 203-216.

Handayani, S. (2015). The Evaluation of English Textbook for Grade VII of Junior High School in Indonesia. Proceedings of the Fourth International Seminar onEnglish Language and Teaching (ISELT-4), 329-339.

Heryuliandini, N., Situmorang, R., \& Suprayekti. (2018). Pengembangan Buku Panduan Mentor di Komunitas Dutak Cilik Anti Rokok. Jurnal Pembelajaran Inovatif Vol 1 (1), 13-18.

Hoshangabadwala, A. (2015). Student Perceptions of Textbook Layout and Learnability in. Journal of Education and Educational Development Vol 2 (1).

Ibrahim, A. A. (2016). Definition Purpose and Procedure of Developmental Research: An Analytical Review. Asian Research Journal of Arts \& Social Sciences Vol 1 (6), 1-6.

Indariani, A., Ayni, N., Pramuditya, S. A., \& Noto, M. S. (2019). Teknologi Buku Digital Matematika dan Penerapan Potensialnya dalam Distance Learning. JNPM (Jurnal Nasional Pendidikan Matematika) Vol 3 (1), 1-12.

Jung, H., \& Kim, Y. R. (2019). Advanced Instructional Design for Successive ELearning: Based on the Successive Approximation Model (SAM). International Journal on E-learning, 191-204.

Kasmaienezhadfard, S. (2015). Effects of Pictures in Textbook on Students on Students' Creativity. Multi Disciplinary Edu Global Quest (Quarterly) Vol 4 (2), 83-96.

Kemendikbud. (2016). Peraturan Menteri Pendidikan dan Kebudayaan No. 8 Tahun 2016. Jakarta: Departemen Pendidikan dan Kebudayaan Indonesia.

Kemendikbud. (2018). Permendikbud No. 37 tahun 2018. Jakarta: Kemendikbud.

Kharisma, J. Y., \& Asman, A. (2018). Pengembangan Bahan Ajar Matematika Berbasis Masalah Berorientasi pada Kemampuan Pemecahan Masalah Matematis dan Prestasi Belajar Matematika. Indonesian Journal of Mathematics Education, 34-46.

Makur, A. P., \& Fed, S. (2018). Pengembangan Buku ajar Statistika Elementer Untuk Mahasiswa Calon. UNION: Jurnal Pendidikan Matematika Vol 6 (3), 339-347.

Matić, L., \& Gracin, D. G. (2016). The use of the textbook as an artefact in the classroom. Journal für Mathematik-Didaktik, 349 - 374.

Millar, M., \& Schrier, T. (2015). Digital or Printed Textbooks: Which do Students Prefer and Why? Journal of Teaching in Travel \& Tourism, 15, 166-185.

Momand, M., Sugunabalan, A., Ibrahim, S. M., \& SC, S. (2019). An Evaluation of Primary School Year 6 (KSSR). International Journal of Engineering and Advanced Technology (IJEAT) Vol $8(5), 1192-1199$.

Ngwenya, J., \& Arek-Bawa, O. (2019). Exploring the quality of Grade 12 accounting education textbooks. The Journal for Transdisciplinary Research in Southern Africa Vol 15 (1), 1-10.

Nordlund, M. (2016). EFL Textbooks for Young Learners: a Comparative Analysis of Vocabulary. Education Inquiry Vol 7 (1), 47-68.

Nurrita, T. (2018). Pengembangan Media Pembelajaran untuk Meningkatkan Hasil Belajar Siswa. Misykat, Vol 3 (1), 171-187.

OECD. (2015). Frascati Manual : Guidelines for Collecting and Reporting Data on Research and Experimental Development. OECD. 
Papajani, J. (2015). The Evaluation of the EFL Textbooks Used in the High Schools of Elbasan, Albania. European Journal of Language and Literature Studies Vol 1 (1), 7-15.

Piskurich, G. M. (2015). Rapid Instructinal Design: Learn ID fast and right. Hoboken, NJ: John Wiley $\&$ Son.

Pokrivcakova, S., \& Pokrivcak, A. (2016). Teaching Materials : Designing Teaching Texts. In Z. Straková, How to Teach in Higher Education : Selected Chapters (p. 106). Prešovská univerzita vPrešove.

Pramika, D., \& Widalismana, M. (2018). Buku Saku sebagai Media Pembelajaran Matematika Ekonomi di Program Studi Pendidikan Akuntansi FKIP Universitas PGRI Palembang. Jurnal Pendidikan Ekonomi UM Metro Vol 6 (1), 1-12.

Radic-Bojanic, B. B., \& Topalov, J. P. (2016). Textbooks in the EFL Classroom. Collection of Papers of the Faculty of Philosophy XLVI (3), 137-153.

Rahmawati, I. Y. (2017). Keterbacaan Buku Bahasa Indonesia (Studi Kasus Buku "Expresi Diri dan Akademik" untuk Kelas X SMA, Kurilkulum 2013). Jurnal Dimensi Pendidikan dan Pembelajaran Vol 5 (2), 90.

Reyhani, E., \& Izadi, M. (2018). Comparative Content Analysis of Mathematics Textbooks Taught to the First Grade Students of Elementary Schools in Iran, Japan and America. International Journal of Industrial Mathematics Vol 10 (3), 299 - 314.

Sar'iyyah, N., Abdullah, A. N., \& Novianti, C. (2018). Model ADDIE Berbasis Kearifan Lokal EndeLio untuk Meningkatkan Kualitas Perkuliahan Desain Pembelajaran IPA. Journal of Elemantary School (JOES) Vol 1 (2), 175-181.

Seel, N. M., Lehmann, T., Blumschein, P., \& Podolskiy, O. A. (2017). Instructional Design for Learning. Rotterdam: Sense Publisher.

Seng, T. K., Yee, L. C., Yeo, J., \& Chow, I. (2014). New Syllabus Mathematics 2 7th Edition. Singapore: Shing Lee Publisher.

Sites, R., \& Green, A. (2014). Leaving ADDIE for SAM Field Guide. Alexandria: ASTD Press.

Sullivan, K. (2015). Judging a Book by Its Cover (and Its background): Effects of the Metaphor Intelligence is Brightness on Ratings of Book Images). Visual Communication Vol 14 (1), 3 14.

Sundayana, R., herman, T., Dahlan, J. A., \& Prahmana, R. C. (2017). Using ASSURE learning design to develop students' mathematical communication ability. World Transactions on Engineering and Technology Education Vol.15 (3), 245-249.

Suryanda, A., Azrai, E. P., \& Julita, A. (2019). Validasi Ahli pada Pengembangan Buku Saku Biologi Berbasis Mind Map (BIOMAP). Biodik: Jurnal Ilmiah Pendidikan Biologi Vol 5 (3), 197-214.

Suryani, N., Ruhimat, M., \& Ningrum, E. (2015). Pengembangan Buku Teks Digital Interaktif untuk Pemahaman Konsep Geografi. Gea, Jurnal Pendidikan Geografi, Vol 15 (2), 46-58.

UNESCO. (2016). Textbooks pave the way to sustainable development . Paris: Global Education Monitoring.

You, J., Lee, H., \& Craig, C. J. (2019). Remaking Textbook Policy: Analysis of National Curriculum Alignment in Korean School Textbooks. Asia Pacific Journal of Education, 1-17. 